\title{
МАСТЕР СВОЕГО ДЕЛА (к юбилею В.Г. Ломана)
}

\section{(C) 2019 г. М.В. Бедельбаева, И.А. Кукушкин}

Статья раскрывает страницы биографии и некоторые итоги научных исследований директора Сарыаркинского археологического института В.Г. Ломана. Вектор его научных интересов направлен на изучение культур эпохи поздней бронзы и исследование технологии изготовления древней керамики. В этой сфере он является признанным специалистом не только в Казахстане, но и за его пределами. Выделение им так называемого донгальского типа керамики заполнило существовавшую до этого лакуну между финальной бронзой и эпохой раннего железа.

Ключевые слова: археология, В.Г. Ломан, Сарыаркинский археологический институт, Центральный Казахстан, эпоха бронзы, донгальская культура, древние технологии, керамика

Валерий Григорьевич Ломан родился 20 марта 1959 года в пос. Чекуновский Туринского района Свердловской области в семье служащих. Исходя из «скупых» воспоминаний юбиляра, можно сделать вывод, что он очень любил своих родителей и особенно нежно относился к маме. В 1967 г. переехал с родителями в город Караганду. До 1976 г. учился в средней школе № 73. Затем поступил на исторический факультет Карагандинского государственного университета, который с отличием окончил в 1981 году с квалификацией «Историк. Преподаватель истории и обществоведения». Одна из главных тем, интерес к которой проявился на старших курсах и не пропадает до сей поры, стала основанием для на- писания дипломной работы «Новые поселения эпохи поздней бронзы Карагандинской области», написанная под руководством В.В. Евдокимова, она получила высокую оценку аттестационной комиссии за самостоятельность в суждениях и выводах, а также предопределила сферу научных интересов будущего специалиста. Непосредственная работа в археологических экспедициях началась еще в студенческие годы: участие в раскопках поселений Конезавод-3, Семиозерное-2, могильников Алпымca, Ащиозек, Карагаш, Конезавод, Сатан; ведение раскопов на поселениях Копа-1, Сатан-1, 2, могильнике Копа. Это позволило сформировать исследовательские навыки и определиться с выбором профессии. 
В 1981 году В.Г. Ломан был принят в Лабораторию археологических исследований при КарГУ в должности старшего лаборанта, а позднее (1985 г.) переведен младшим научным сотрудником для работы по хоздоговорным темам, заключаемым с Обществом охраны памятников истории и культуры Казахской ССР на разведки и охранные раскопки археологических памятников. В ходе активного участия в организации и работе археологической экспедиции университета происходит становление В.Г. Ломана как исследователя. Он являлся научным консультантом студенческого научноисследовательского археологического отряда «Краевед», работал со студентами, специализирующимися на кафедре «История Казахской ССР». За создание экспозиции музея архе- ологии и этнографии университета вместе с коллегами (В.В. Евдокимов, И.В. Рудковский, К.М. Карабаспакова, В.В. Варфоломеев, В.А. Новоженов, Э.Р. Усманова) был выдвинут на соискание премии Ленинского комсомола Казахстана.

В 1986-1988 гг. был направлен для работы стажером-исследователем в Лабораторию истории керамики Отдела теории и методики Института археологии АН СССР (г. Москва), а в декабре 1989 г. поступил туда в очную целевую аспирантуру. Вот выдержка из служебной характеристики В.Г. Ломана, представленной при поступлении в аспирантуру и подписанной ректором КарГУ А. Бигалиевым и секретарем парткома Ю. Антиповым: «Целеустремлен, работоспособен, имеет высокий уровень профессиональной подготовки,

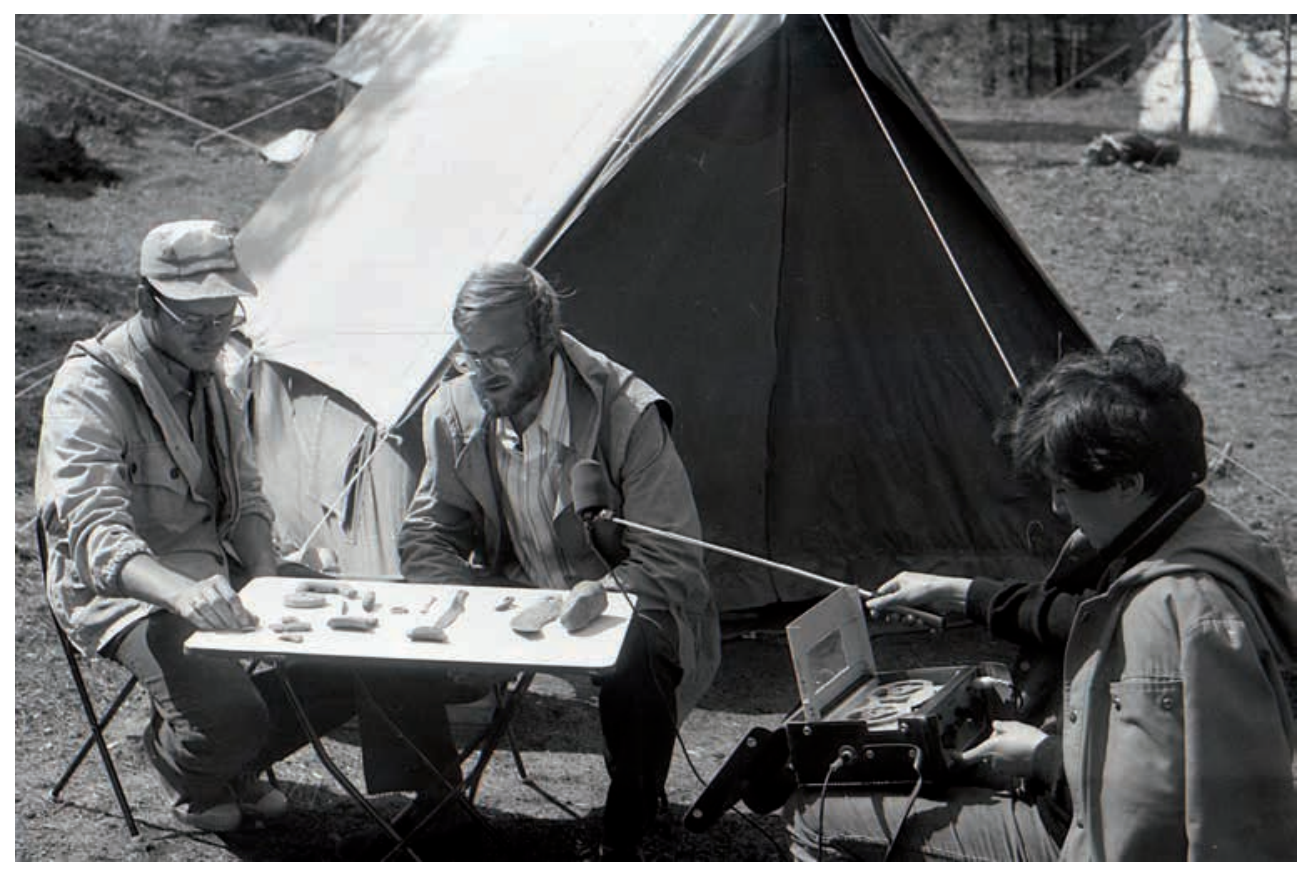

Рис. 1 В.Г. Ломан и В.В. Варфоломеев дают интервью на съемках документального фильма об исследованиях поселения Кент, 19852.

Фото из личного архива В.В. Варфоломеева

Fig. $1 \mathrm{~V}$. Loman and V. Varfolomeev give interview for a documentary film about the research of the settlement of Kent, 1985. Photo from the personal archive of V. Varfolomeev 
что позволяет ему успешно справляться с поставленными перед ним задачами» (материалы личного дела). В крупнейшем научном центре под руководством доктора исторических наук А.А. Бобринского В.Г. Ломан освоил методику изучения технологии изготовления древней керамики и начал работу над научной темой по данной проблематике. В ноябре 1993 г. в Институте археологии РАН успешно защитил диссертацию на соискание ученой степени кандидата исторических наук по теме «Гончарная технология населения Центрального Казахстана второй половины II тыс. до н.э.» (шифр специальности: 07.00.06.).

В 1993 г. В.Г. Ломан вернулся в Караганду и был зачислен инженером Лаборатории-музея археологических исследований КарГУ. С 1995 по 2003 гг. являлся заведующим совместным Отделом археологии Центрального Казахстана КарГУ и Института археологии им. А.X. Маргулана, преобразованного в 2003 г. в Сарыаркинский археологический институт при КарГУ им. академика Е.А. Букетова. С 2005 г. - директор САИ. Стаж работы в КарГУ составляет более 35 лет. За плодотворную деятельность в системе высшего образования, существенный вклад в развитие университета награжден почетной грамотой (2009 г.) и юбилейной медалью «40 лет КарГУ им. Е.А. Букетова» (2012г.), удостоен звания «Заслуженный работник КарГУ им. Е.А. Букетова» (2015 г.).

Ломан В.Г. - автор и соавтор более 100 научных работ, в том числе четырех монографий, ответственный редактор ряда сборников научных статей и монографий. Результаты его научной деятельности получили широкое признание коллег как в Казахстане, так и за его пределами. В частности, выделение им так называемого донгальского типа керамики, датированного тогда VIII в. до н.э., заполнило существовавшую до этого лакуну между финальной бронзой и эпохой раннего железа. В течение ряда лет памятники с керамикой этого типа были обнаружены не только в Казахстане, но и на территории Алтая, что говорит о правомерности его выделения и необходимости дальнейшего изучения. Таким образом, поселение Донгал является эпонимным памятником, давшим название особому историкокультурному явлению, признанному археологами Казахстана и России и имеющим большую значимость в ряду объектов культурного наследия нашей республики. Формирование донгальских комплексов связано с изменением природно-климатической ситуации в степной зоне Казахстана на рубеже II-I тыс. до н.э., поиском и развитием новых направлений хозяйственной деятельности, перестройкой хозяйства и началом освоения железа (практически на всех донгальских поселениях обнаружены металлургические шлаки с высоким содержанием железа). По материалам донгальского типа прослеживается явная генетическая связь между культурами финальной бронзы и раннего железного века. Задача поиска и обоснования этой связи является одной из главнейших для археологии.

Помимо этого, В.Г. Ломан остается единственным в Казахстане специалистом по древней гончарной технологии. Работая очень организованно и целенаправленно, В.Г. Ломан достиг высокого авто- 


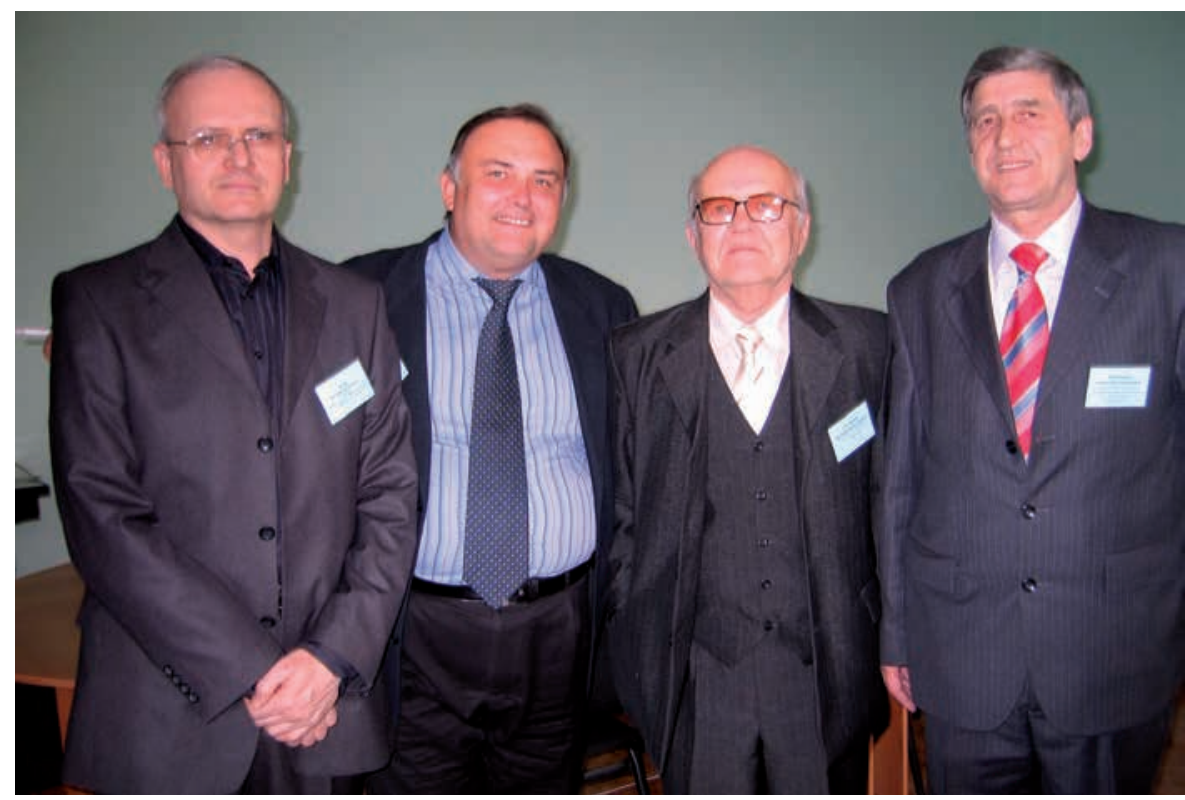

Рис. 3. В.Г. Ломан, В.А. Новоженов, В.В. Евдокимов, А.А. Плешаков (слева-направо) на международной конференции «Маргулановские чтения - 2008».

КарГУ им. Е.А. Букетова, март 2008 г. Фото Э.Р. Усмановой

Fig. 3. V. Loman, V. Novozhenov, V. Evdokimov, A. Pleshakov (left to right) at the international conference "Murgulan readings - 2008».

KSU academician E.A. Buketov, March 2008. Photo by E. Usmanova

ритета среди коллег-археологов. По приглашению Алтайского госуниверситета, как признанный специалист в области технологии древнего гончарного производства, проводил технико-технологический анализ керамики из раскопок археологической экспедиции АлтГУ. Детальные и обстоятельные исследования технологических процессов гончарного производства вкупе с анализом всех доступных изучению аспектов и взаимная корреляция источников составили надежную платформу тщательно подготовленным коллективным монографиям и публикациям, которые предоставляют ценные свидетельства исторического порядка. Тщательный анализ технических приемов и детальное изучение системы изготовления керамики, ее состава позволили исследователю выде- лить различия в «почерке» изготовителей, что сделало самый массовый материал археологических памятников основанием для исторических выводов.

В.Г. Ломан активно занимается популяризацией знаний о древней истории Казахстана, является соавтором научно-популярных фильмов по археологии, выступает в средствах массовой информации. Совместно с ведущим научным сотрудником САИ И.А. Кукушкиным разработал и внедрил в Карагандинском областном историко-краеведческом музее уникальную экспозицию компьютерной анимации палеоантропологических реконструкций «Лики предков». Она по праву может считаться единственной в своем роде, не имеющей аналогов в Казахстане и за рубежом, о чем получено авторское свидетельство 
Бедельбаева М.В., Кукушкин И.А. Мастер своего дела (к юбилею В.Г. Ломана)

№ 129 от 7 августа 2001 г. «Компьютерная анимация антропологических портретных реконструкций и их экспонирование», выданное Комитетом по авторским правам Министерства юстиции Республики Казахстан.

В течение ряда лет Валерий Григорьевич плодотворно руководит и участвует в разработке научных проектов, финансируемых Комитетом науки МОН РК («Культуры финальной бронзы Казахстана как основа сложения степной цивилизации номадов»; «История населения степной зоны Казахстана эпохи бронзы - начала раннего железного века (по данным гончарной технологии)» и др.).

В.Г. Ломан неоднократно участвовал в международных (Германия, Китай, Турция, Россия, Украина) и республиканских археологических

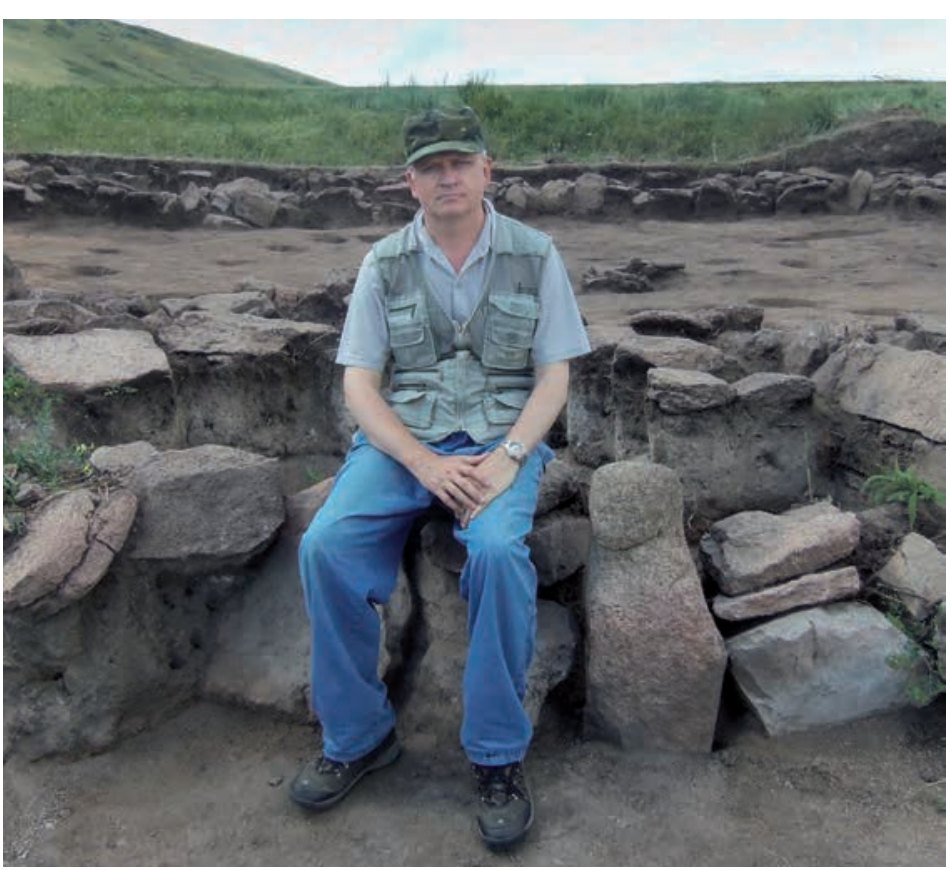

Рис. 2 В. Г. Ломан на раскопках поселения Донгал, 2012 2. Фото из архива САИ

Fig. 2 V. Loman on the excavations of the settlement Dongal, 2012. Photo from SAI archive конференциях и совещаниях в марте 2005 года в составе делегации Казахстана проходил стажировку, обучаясь на факультете археологии Каирского университета (Египет).

Значительная часть научной деятельности В.Г. Ломана связана с полевыми экспедиционными и стационарно-лабораторными исследованиями. Он исследовал такие памятники, как поселения Донгал, Кент, Бугулы-1, могильники Аксу-Аюлы-2, Дарьинский, Каратугай, Кудрявая Сопка-1, Кулаайгыр, Лисаковский, Майбулак-2, Нураталды-1, 2, Окуле-4, 5, Тасырбай, Ташик. Многое сделано им для обеспечения сохранности объектов историко-культурного наследия области при освоении территорий: паспортизация, составление реестра, мониторинг состояния памятников, утверждение охранных зон в рамках исполнения требования законов РК.

Педантич ность и скрупулезность в подходах и выборе методик обработки материала снискали ему заслуженный авторитет серьезного и компетентного ученого, обладающего энциклопедическими знаниями и широчайшим научным кругозором. Является положительным примером и такое качество, как систематичная формализованная (в лучшем смысле этого понятия) фондовая работа, 
которая проводится с целью сохранить все артефакты для научного исследования. При подготовке международной выставки «Неизвестный Казахстан: археология в центре Евразии», которая проводилась в г. Бохум (Германия) в 2012 г., из фондов музея археологии и этнографии САИ было использовано около 100 экспонатов, каталогизация которых показала надлежащие условия документирования и хранения артефактов, в чем есть немалая заслуга В.Г. Ломана. И это бесценный опыт, достигнутый классическим образованием, честностью в исполнении профессиональных обязанностей, ответственностью перед будущими поколениями исследователей.

В силу врожденной наблюдательности и, вероятно, абсолютного слуха В.Г. Ломан является флагманом САИ в освоении иностранных языков, проявляя определенную склонность к сравнению фонетических форм и языковых взаимопроникновений. Нельзя не отметить его владение иностранными языками, в частности, английским и польским, что позволяет свободно общаться с коллегами целого ряда зарубежных научных центров, проводить совместные исследовательские работы и публиковаться в высокорейтинговых журналах. Беспристрастность и тактичность в обращении с коллегами, умение как директора САИ решать управленческие задачи и найти персональный подход к каждому сотруднику, сформировали деловой климат, необходимый для плодотворной работы всего коллектива. Надежной оценкой его профессиональной деятельности является и общее увеличение грантового финансирования, расширение объемов хоздоговорных работ, а также количественное и качественное усиление публикационной активности сотрудников САИ.

\section{Очевиден личный интерес}

В.Г. Ломана к техническим новинкам и компьютерным разработкам, используемым в археологии. Его ценные советы и рекомендации в этой области очень ценят все сотрудники САИ, что позволяет расширить корпус исследовательских методов в археологии.

Как директор САИ и ученый В.Г. Ломан оказывает значительную помощь молодым исследователям. Это проявляется в рамках консультаций при выборе научной тематики, мотивированием на исследования, компетентным советом в теории и практике, написании объективной рецензии. Но главное - это личный пример, базирующийся на 35 годах непрерывного научного стажа и свидетельствующий о преданности своей профессии, оставшейся неизменной исследовательской стезе археолога, несмотря на все зигзаги современной истории. Определенным признанием этого факта является почетная грамота акима города Караганды за вклад в социально-экономическое развитие и активное участие в общественнополитической жизни города, которой в 2012 г. был награжден В.Г. Ломан.

Характеризуя человеческие качества юбиляра, следует отметить, что как натура незаурядная и своеобразная, В.Г. Ломан не сразу «раскрывается» в общении. Его ирония, частенько переходящая в сарказм, порой сложно воспринимается окружающими. Однако, компетентентность и эрудированность во многих сферах, неконфликтность, обязательность, профессионализм подтверждены не только его официальным статусом директора САИ, но и атмосферой уважения в научном сообществе.

У нашего именинника крепкая и дружная семья - супруга Надежда Филипповна, бывшая однокурс- 
ница, преподаватель общественнополитических дисциплин в Карагандинском государственном медицинском университете, и взрослая дочь с чудесным именем Марианна.

От лица археологического сообщества искренне желаем юбиляру крепкого здоровья, счастья, молодо- сти души, благополучия родным и близким! Мы уверены, что глубокие знания, богатый жизненный опыт, профессионализм, мудрость и лучшие человеческие качества В.Г. Ломана помогут внести неоценимый вклад в развитие археологии.

\section{Список основных публикаций В.Г. Ломана}

\section{Автореферат:}

Гончарная технология населения Центрального Казахстана второй половины II тысячелетия до н.э.: автореф. дис. ... канд. ист. наук (шифр специальности: 07.00.06.). М.: Институт археологии РАН, 1993. 31 с.

Монографии:

Археологическая карта Каркаралинского района Карагандинской области. Алматы: Иль-тех-Китап, 2004. 256 с. (в соавт. с Бейсеновым А.З., Евдокимовым В.В., Тулеуовым Т.С.).

Древние поселения Центрального Казахстана. Алматы: «Інжу-Маржан» полиграфия, 2009. 264 с. (в соавт. с Бейсеновым А.3.).

Кент - город в центре казахских степей. Материалы и исследования по культурному наследию. Т. ХІ. Астана: КазНИИ культуры, 2017. 338 с. (в coaвm. c Варфоломеевым В.В., Евдокимовым В.В.).

Поселения сакской эпохи. Алматы: НИЦИА «Бегазы-Тасмола», 2017. 208 с. (в соавт. с Бейсеновым А.З., Шульгой П.И).

Статьи в казахстанских изданиях:

Поселение Копа I// Вопросы археологии и этнографии Центрального Казахстана. Караганда: КарГУ, 1982. С. 20-41 (в соавт. с Евдокимовым В.В.).

Донгальский тип керамики // Вопросы периодизации археологических памятников Центрального и Северного Казахстана. Караганда: КарГУ, 1987. C. $115-129$.

Раскопки ямного кургана в Карагандинской области // Вопросы археологии Центрального и Северного Казахстана. Караганда: КарГУ, 1989. С. 34-46 (в соавт. с Евдокимовым В.В.).

О культурных типах памятников финала эпохи бронзы Казахстана // Бегазыдандыбаевская культура степной Евразии: сб. научн. ст., посвящ. 65-летию Ж. Курманкулова. Отв. ред. А.З. Бейсенов. Алматы: НИЦИА «Бегазы-Тасмола», 2013. C. 247-259.

Статьи в международных рейтинговых изданиях:

Результаты технико-технологического анализа образцов керамики поселения Эль Конвенто, Куба // РА. 1992. № 2. С. 258-269 (в соавт. с Бобринским А.А.).

Краниологические материалы эпохи бронзы Казахстана // ВААЭ. 2013. № 3 (22) (в соавт. с Солодовниковым К.Н., Рыкун М.П.). 
Привозная керамика на поселении Кент // Самарский научный вестник. 2015. № 4 (13). С. 71-79.

Результаты технико-технологического анализа керамического комплекса поселения эпохи поздней бронзы Рублево VI // ТПАИ. 2015. № 2 (12). C. 115-143 (в соавт. с Папинымм Д.В., Степановой Н.Ф., Федоруком А.С.).

Позднеирменская керамика Барнаульского Приобья (технико-технологический аспект) // Известия АлтГУ. 2015. № 4/2 (88). С. 141-146 (в соавт. с Д.В. Папинымм).

Погребение с металлическим сосудом в могильнике Нураталды-1 (эпоха бронзы) // Уральский исторический вестник. 2016. № 4 (53). С. 79-86 (в соавт. с Кукушикинымм И.А., Кукушкиным А.И., Дмитриевым Е.А.).

Керамический комплекс поселения Фирсово-XVIII (технико-технологический аспект) // Известия АлтГУ. № 4 (92). 2016. С. 262-267 (в соавт. с Папиным Д.В., Федоруком А.С.).

Керамический комплекс эпохи поздней бронзы поселения Жарково-3 // ТПАИ. 2016. № 3 (15). С. 102-125 (в соавт. с Папиным Д.В., Федоруком А.С., Степановой Н.Ф.).

Гончарная технология поселений сакского времени Казахского мелкосопочника // Евразия в кайнозое. Стратиграфия, палеоэкология, культуры. 2016. Вып. 5. С. 240248 (в соавт. с Бейсеновым А.3.).

Связи населения юга Западной Сибири и Средней Азии в эпоху поздней бронзы (по материалам керамических комплексов) // Вестник ТомГУ. История. 2017. № 49. С. 32-36 (в соавт. с Папиным Д.В., Федоруком А.С.).

Новые исследования керамики поселений Атасу и Мыржык // Известия АлтГУ. 2017. № 2 (94). С. 221-225 (в соавт. с Бейсеновым А.3.).

The Making of Bronze Age Eurasia, by Philip L. Kohl. Review // American Journal of Archaeology. № 113. 3. (July 2009). P. 483-485.

How 'Pastoral' is Pastoralism? Dietary Diversity in Bronze Age Communities in the Central Kazakhstan Steppes // Archaeometry, Vol. 57, Issue S1, July 2015 (University of Oxford). P. 232-249. (в coaвm. с E. Lightfoot, G. Motuzaite-Matuzeviciute, T.C. O'Connell, X. Liu and M. K. Jones, I. Kukushkin, V. Varfolomeev).

The extent of cereal cultivation among the Bronze Age to Turkic period societies of Kazakhstan determined using stable isotope analysis of bone collagen // JAS. Vol. 59, July 2015. P. 23-34 (в соавт. с G. Motuzaite Matuzeviciute, E. Lightfoot, E. Usmanova, T.C. O'Connell, D. Voyakin, X. Liu, S. Svyatko, M.K. Jones).

137 ancient human genomes from across the Eurasian steppes // Nature. 17 May 2018. Vol. 557, No 7705. P. 369-374. (в coaвm. c P. de B. Damgaard, N. Marchi, S. Rasmussen, M. Peyrot, G. Renaud, Th. Korneliussen, J. V. Moreno-Maya, M. W. Pedersen, A. Goldberg, etc.).

Статьи в сборниках:

Компьютерная программа для аналитического изучения форм керамических сосудов // Современные проблемы археологии России. Новосибирск: ИАЭТ СО РАН, 2006. С. $476-477$.

Вопросы гончарной технологии населения андроновской культурноисторической общности в археологической литературе // Древнее гончарство: итоги и перспективы изучения. М.: ИА РАН, 2010. С. 214-224.

К вопросу о генезисе и составе населения саргаринско-алексеевской культуры (по данным технико-технологического анализа керамики) // Современные подходы к изучению древней керамики в археологии. М.: ИА РАН, 2015. С. 243-247.

\section{Сведения об авторах:}

Бедельбаева Марина Васильевна - кандидат исторических наук, заведующая музеем археологии и этнографии, Сарыаркинский археологический институт, 
Карагандинский государственный университет им. Е.А. Букетова (г. Караганды, Казахстан); bmv_1967@mail.ru

Кукушкин Игорь Алексеевич, кандидат исторических наук, ВНС, Сарыаркинский археологический институт, Карагандинский государственный университет им. Е.А. Букетова (г. Караганды, Казахстан); sai@ksu.kz

\section{Ө3 ІСІНІН ШЕБЕРI \\ (В.Г. Ломанның мерейтойына арналған)}

\section{М.В. Беделбаева, И.А. Кукушкин}

Мақала Сарыарқа археологиялық институтының директоры В.Г. Ломанның өмірбаян беттері мен ғылыми зерттеулер нәтижелерін ашуға арналған. Оның ғылыми ізденістерінің саласы соңғы қола дәуірі мәдениеттерін зерттеуге және ежелгі қыш дайындау технологиясы әдісіне бағытталған және осы бағыт бойынша ол Қазақстанда ғана емес, одан да тыс аймақтарда танымал маман. Оның ерекше бөліп қарастырған қыштың доңғалдық типі осыған дейінгі қола және ерте темір дәуірлерінің арасындағы ашық болып келген олқылықтарды толтырды.

Түйін сөздер: археология, В.Г. Ломан, Сарыарқа археологиялық институты, Орталық Қазақстан, қола дәуірі, доңғал мәдениеті, ежелгі технологиялар, қыш

\section{MASTER-HAND OF HIS CRAFT (for the anniversary of V.G. Loman)}

\section{M.V. Bedelbayeva, I. A. Kukushkin}

The article reveals the pages of biography and results of scientific researches of the director of Saryarka archaeological institute V. G. Loman. The vector of his scientific interests is aimed at studying the cultures of the Late Bronze Age and the method of studying the technology of making ancient ceramics, in which he is a recognized expert not only in Kazakhstan but also abroad. His eduction of the so-called dongal type of ceramics filled the gap between the final bronze and the Early Iron Age.

Keywords: archaeology, V. G. Loman, Saryarka archaeological institute, Bronze Age, Central Kazakhstan, dongal culture, ancient technologies, ceramics

\section{About the Authors:}

Bedelbayeva Marina V. Candidate of historical sciences, director archaeology and ethnography museum, Saryarka archaeological Institute, Karagandy State University after academician E.A. Buketov, Karagandy, Kazakhstan; bmv_1967@mail.ru

Kukushkin Igor A. Candidate of historical sciences, Leader researcher, Saryarka archaeological institute, Karagandy State University after academician E.A. Buketov, Karagandy, Kazakhstan; sai@ksu.kz

Мақала туралы ақпарат / Информация о статье / Information about the article. Редакцияға түсті / Поступила в редакцию / Entered the editorial office: 15.03.2019. 